\title{
Safe and effective performance of pediatric spinal deformity surgery in patients unwilling to accept blood transfusion: a clinical study and review of literature
}

\author{
Alexander Mihas ${ }^{1}$, Subaraman Ramchandran ${ }^{2 *}$, Sebastian Rivera ${ }^{3}$, Ali Mansour ${ }^{2}$, Jahangir Asghar ${ }^{4}$,
} Harry Shufflebarger ${ }^{5}$ and Stephen George ${ }^{2}$

\begin{abstract}
Background: Pediatric deformity surgery traditionally involves major blood loss. Patients refusing blood transfusion add extra clinical and medicolegal challenges; specifically the Jehovah's witnesses population. The objective of this study is to review the safety and effectiveness of blood conservation techniques in patients undergoing pediatric spine deformity surgery who refuse blood transfusion.
\end{abstract}

Methods: After obtaining institutional review board approval, we retrospectively reviewed 20 consecutive patients who underwent spinal deformity surgery and refused blood transfusion at a single institution between 2014 and 2018. We collected pertinent preoperative, intraoperative and most recent clinical and radiological data with latest follow-up (minimum two-year follow-up).

Results: Twenty patients (13 females) with a mean age of 14.1 years were identified. The type of scoliotic deformities were adolescent idiopathic (14), juvenile idiopathic (1), neuromuscular (3) and congenital (2). The major coronal Cobb angle was corrected from $55.4^{\circ}$ to $11.2^{\circ}$ (80\% correction, $p<0.001$ ) at the latest follow-up. A mean of 11.4 levels were fused and 5.6 levels of Pontes osteotomies were performed. One patient underwent L1 hemivertebra resection and three patients had fusion to pelvis. Estimated blood loss, percent estimated blood volume loss, and cell saver returned averaged $307.9 \mathrm{~mL}, 8.5 \%$, and $80 \mathrm{~mL}$, respectively. Average operative time was $214 \mathrm{~min}$. The average drop in hemoglobin after surgery was $2.9 \mathrm{~g} / \mathrm{dL}$. The length of hospital stay averaged 5.1 days. There were no intraoperative complications. Three postoperative complications were identified, none related to their refusal of transfusion. One patient had in-hospital respiratory complication, one patient developed a late infection, and one patient developed asymptomatic radiographic distal junctional kyphosis.

Conclusions: Blood conservation techniques allow for safe and effective spine deformity surgery in pediatric patients refusing blood transfusion without major anesthetic or medical complications, when performed by an experienced multidisciplinary team.

Level of evidence: Level IV.

Keywords: Scoliosis, Blood loss, Jehovah's witness, Blood transfusion, Blood salvage, Spinal deformity correction

\footnotetext{
* Correspondence: subbu_gsmc@yahoo.co.in

${ }^{2}$ Department of Orthopedic Surgery, Nicklaus Children's Hospital, 3100 SW 62nd Avenue, Miami, FL 33155, USA

Full list of author information is available at the end of the article
}

C C The Author(s). 2021 Open Access This article is licensed under a Creative Commons Attribution 4.0 International License, which permits use, sharing, adaptation, distribution and reproduction in any medium or format, as long as you give appropriate credit to the original author(s) and the source, provide a link to the Creative Commons licence, and indicate if changes were made. The images or other third party material in this article are included in the article's Creative Commons licence, unless indicated otherwise in a credit line to the material. If material is not included in the article's Creative Commons licence and your intended use is not permitted by statutory regulation or exceeds the permitted use, you will need to obtain permission directly from the copyright holder. To view a copy of this licence, visit http://creativecommons.org/licenses/by/4.0/. The Creative Commons Public Domain Dedication waiver (http://creativecommons.org/publicdomain/zero/1.0/) applies to the data made available in this article, unless otherwise stated in a credit line to the data. 


\section{Background}

Surgical intervention for spinal deformities is associated with substantial blood loss [1], which is of special concern in pediatric patients due to their smaller blood volume in comparison to adults [2]. Allogeneic blood transfusion rates in pediatric patients undergoing posterior spinal fusion have been reported to range from 17.5 to $19.3 \%$ [3, 4], with some institutions reporting rates as high as $31 \%$ [5]. However, allogeneic blood transfusions are associated with various risks: infections, immunomodulation, hemolytic reactions, allergic reactions, circulatory overload, and acute lung injury [6, 7]. Furthermore, one study showed that transfusion of just a single unit of blood prolonged hospital stay length and increased postoperative morbidity in patients who underwent elective spine surgery, independent of patient comorbidities and preoperative hematocrit levels [8].

In addition to the potential complications of allogeneic blood transfusions, patients may refuse blood transfusions due to personal or religious reasons. The Jehovah's Witnesses (JW) are a Christian denomination who notably refuse blood transfusions due to their interpretation of several biblical passages that refer to blood as sacred and prohibit its consumption [9]. As a result, JW do not accept whole blood (including autologous) nor its main components of plasma, red blood cells, white blood cells, and platelets; however, each member is left to their own personal discretion in regards to accepting blood fractions (e.g. immunoglobulins and clotting factors) [10].

Performing invasive procedures in patients who do not accept blood products poses ethical, clinical, and medicolegal challenges for surgical personnel. Such circumstances create friction between a physician's duty to provide optimal care and respect patient autonomy [11]. Moreover, caring for these patients requires thorough preoperative screening and management for conditions such as anemia and coagulopathy [12, 13]. From a legal perspective, although competent adults reserve the right to refuse medical treatment for themselves [14], if parental decisions endanger a child's life, the child's welfare takes priority [15]. These challenges unfortunately become more complex if the situation involves minors or elective procedures since court decisions have been inconsistent in these cases $[15,16]$.

Due to the morbidity associated with blood loss and transfusion, and the growing population of patients who do not accept blood products, numerous blood conservation techniques have been developed in an attempt to improve patient outcomes $[17,18]$. Preoperative strategies mainly consist of raising hemoglobin levels with recombinant human erythropoietin or iron supplementation $[19,20]$. Perioperative techniques include proper patient positioning [21], controlled hypotensive anesthesia (HA) [22-24], acute normovolemic hemodilution (ANH) [25], intraoperative cell salvage (ICS) [26-28], topical hemostatic agents [29], antifibrinolytics (e.g. aminocaproic acid and tranexamic acid) [30-35], and lastly, certain surgical tools can also reduce blood loss such as full electrocautery dissection, bipolar tissue sealants [36], and ultrasonic bone cutting tools for performing osteotomies [37, 38]. It should be noted that JW patients may request that ANH and ICS equipment maintain continuity with their vascular system as they may otherwise equate these methods to autologous blood transfusion [9]. Few studies have investigated the use of blood conservation techniques in spinal deformity procedures in patients who are unwilling to accept blood products [16, 39]. The objective of this study is to evaluate the outcomes of adolescent patients who underwent spinal deformity correction procedures and refused blood transfusions. We hypothesize that by employing various blood conservation techniques, these procedures can be performed safely and effectively by an experienced multidisciplinary team.

\section{Methods}

After obtaining Institutional Review Board approval, a retrospective review of radiographic and medical records was performed to identify patients who refused blood transfusion prior to undergoing spinal deformity surgery between 2014 and 2018 at a single institution. All patients underwent single stage, posterior instrumentation and fusion for scoliosis with the use perioperative blood salvage techniques. Exclusion criteria included any patient that (1) received blood transfusion or blood products, or (2) underwent revision surgery.

All patients received a detailed preoperative hematology work-up and iron supplementation for 4 weeks prior to surgery. Preoperative discussion involved detailed advantages and risks of surgical procedure. All patients and family were questioned about their preferences regarding acceptance of cell saver blood. The families were counselled regarding the possibility of staged procedure. Clinically, an intraoperative blood loss of more than $50 \%$ of estimated blood volume or hypotension requiring pressors to maintain the mean arterial pressure of $75 \mathrm{mmHg}$ was used as a threshold for staging the procedure. Intraoperative blood salvage techniques were also used for all patients. Prior to incision, all patients received a bolus of $50 \mathrm{mg} / \mathrm{kg}$ of tranexamic acid, followed by continuous infusion of $5 \mathrm{mg} / \mathrm{kg}$. Hypotensive anesthesia was performed during surgical dissection with a mean arterial pressure of $60-70$ mmHg. Skin incision was injected with $1 \%$ Lidocaine with 1:100,000 epinephrine solution. Careful subperiosteal dissection was carried out using electrocautery and bipolar tissue sealer device was used as needed to 
aid with hemostatic control. Furthermore, topical tranexamic acid (TXA) was used in the form of 1:1 dilution with normal saline as TXA soaked sponges, which were packed in areas of wound that were outside of area of interest. Surgifoam (Johnson \& Johnson), an absorbable gelatin powder, was used over decorticated surfaces, Ponte osteotomy sites, and pedicle screw holes for additional hemostasis. In addition, for facetectomies and when applicable, vertebral body decancellation was performed using ultrasonic bone cutting devices. Cell saver was used throughout procedure to capture blood loss. Hemoglobin was measured preoperatively and monitored throughout the intraoperative and postoperative periods. Superficial drains were used in all patients, which were removed on the first postoperative day after first mobilization.

Data collected from patient records included patient demographics (age, gender, body mass index, diagnosis and comorbidities); radiographic variables (curve type, coronal Cobb angles, truncal shift, thoracic kyphosis, spinopelvic parameters); surgical variables (estimated blood loss [EBL], percent estimated blood volume loss [\% EBVL], operative time, number of fusion levels, type and number of osteotomies, number of thoracoplasty levels, type of instrumentation, iliac fixation and interbody fusion if employed) and perioperative outcomes including complications, length of stay in ICU, hospital length of stay, intraoperative and postoperative hemoglobin. EBL was calculated using the blood collected in the cell saver and weighted soaked sponges after taking into consideration the amount of saline irrigation used and was recorded periodically throughout the procedure. Estimated blood volume (EBV) was calculated as $70 \mathrm{~mL} / \mathrm{kg}$ (body weight) [1]. Frequency distributions were completed for demographic and perioperative variables. All continuous variables are presented mean \pm standard deviation. Preoperative and postoperative radiographic measurements were compared using paired sample t-tests, where $p$-values of $<0.05$ were considered significant. Analysis was performed separately for idiopathic and non-idiopathic (congenital and neuromuscular scoliosis) patients. All statistics were conducted with SPSS 25 software.

\section{Results}

\section{Demographic and surgical variables}

A total of 20 patients who refused blood transfusions met the inclusion criteria for this study, 13 (65\%) of which were females. The study population had a mean age of $14.1 \pm 2.4$ years and a mean BMI of $22.8 \pm 5.8$. Of these patients, 14 patients $(70 \%)$ had adolescent idiopathic scoliosis (AIS), 1 (5\%) had juvenile idiopathic scoliosis (JIS), 2 (10\%) had congenital, and 3 (15\%) had neuromuscular scoliosis. Among the 14 patients with AIS, Lenke classifications were as follows: 1 (7.1\%) type 1A curve, 5 (35.7\%) type 1B curves, 1 (7.1\%) 1C curve, 1 (7.1\%) type 3C curve, 4 (28.6\%) type $5 \mathrm{C}$ curves, and 2 (14.2\%) 6C curves. Mean Risser score for patients in the study was $3.8 \pm 1.3$. None of the idiopathic or congenital patients had any medical comorbidities. Two of the patients with neuromuscular scoliosis had comorbidities including severe gastroesophageal reflux, seizure disorder and restrictive lung disease. One of the patients also had severe cardiac comorbidities including patent ductus arteriosus (repaired), coarctation of aorta (repaired) and bicuspid aortic valve.

There was a mean of $11.4 \pm 3.1$ levels fused and $5.6 \pm$ 3.1 levels of Pontes osteotomies, as well as $3.7 \pm 1.8$ levels of thoracoplasty in the idiopathic group. One patient (5\%) received a hemivertebra resection and three patients (15\%) received iliac fixation. Means for EBL, \% EBVL, cell saver returned, and total fluids transfused were $307.9 \pm 134.8 \mathrm{~mL}, 8.5 \pm 5.0 \%, 80.4 \pm 56.0 \mathrm{~mL}$, and $2201.2 \pm 562.7 \mathrm{~mL}$, respectively, with a mean operative time of $214.6 \pm 65.4 \mathrm{~min}$. None of the patients in the study were staged due to increased intraoperative blood loss. Separate values for idiopathic and non-idiopathic groups can be found in Table 1 .

\section{Outcome variables}

The mean decrease between preoperative and postoperative hemoglobin levels was $2.7 \pm 0.9 \mathrm{~g} / \mathrm{dL}$ in the idiopathic group and $3.9 \pm 2.9 \mathrm{~g} / \mathrm{dL}$ in the non-idiopathic group. There were no intraoperative complications and the average length of hospital stay was $4.9 \pm 0.6$ days and $5.4 \pm 2.1$ days in the idiopathic and non-idiopathic groups, respectively. Three postoperative complications were identified, which were not related to refusing transfusions. One patient had perioperative atelectasis requiring respiratory support, one patient developed a late infection, which needed antibiotics with revision and one patient developed asymptomatic radiographic distal junctional kyphosis, which also required revision (Table 1). Two of the neuromuscular scoliosis patients were transferred to ICU ( 5 days and 1 day, respectively) after surgery. At latest follow-up (minimum two-year follow-up), the mean major coronal Cobb angle was corrected from $49.6 \pm 6.4^{\circ}$ to $7.8 \pm 3.1^{\circ}$ in the idiopathic group and $72.8 \pm 29.4^{\circ}$ to $21.0 \pm 11.8^{\circ}$ in the non-idiopathic group (Fig. 1). The patient who underwent a hemivertebra excision at $\mathrm{L} 1$ had a change in the coronal Cobb angle from $43^{\circ}$ to $11^{\circ}$ with an EBL and \% EBVL of $100 \mathrm{~mL}$ and $1.7 \%$, respectively (Fig. 2). Perioperative changes in radiographic and clinical variables can be found in Table 2 . 
Table 1 Demographics, surgical variables, and immediate postoperative outcomes in adolescent patients with spinal deformity correction who refused blood transfusion

\begin{tabular}{|c|c|c|}
\hline & $\begin{array}{l}\text { Idiopathic } \\
(n=15)\end{array}$ & $\begin{array}{l}\text { Non-Idiopathic } \\
(n=5)\end{array}$ \\
\hline \multicolumn{3}{|l|}{ Demographic Variables } \\
\hline Age (years) & $14.7 \pm 2.6$ & $12.4 \pm 0.9$ \\
\hline \multicolumn{3}{|l|}{ Gender (n, \%) } \\
\hline Female & $10(66.7 \%)$ & $3(60 \%)$ \\
\hline Male & $5(33.3 \%)$ & $2(40 \%)$ \\
\hline $\mathrm{BMI}\left(\mathrm{kg} / \mathrm{m}^{2}\right)$ & $22.5 \pm 5.4$ & $23.9 \pm 7.8$ \\
\hline \multicolumn{3}{|l|}{ Diagnosis (n, \%) } \\
\hline AIS & $14(93.3 \%)$ & 0 \\
\hline JIS & $1(6.7 \%)$ & 0 \\
\hline Congenital & 0 & $2(40 \%)$ \\
\hline Neuromuscular & 0 & $3(60 \%)$ \\
\hline Hemoglobin (g/dL) & $13.3 \pm 0.9$ & $13.8 \pm 1.5$ \\
\hline \multicolumn{3}{|l|}{ Surgical Variables } \\
\hline Number of Fusion Levels & $10.9 \pm 2.3$ & $13.0 \pm 4.8$ \\
\hline Number of Ponte Osteotomies & $5.7 \pm 2.5$ & $5.8 \pm 5.6$ \\
\hline Number of Thoracoplasty Levels & $3.7 \pm 1.8$ & 0 \\
\hline Hemivertebra Resection (n, \%) & 0 & $1(20 \%)$ \\
\hline Iliac Fixation (n, \%) & 0 & $3(60 \%)$ \\
\hline $\mathrm{EBL}(\mathrm{mL})$ & $286.3 \pm 126.0$ & $372.6 \pm 154.2$ \\
\hline$\%$ EBVL & $7.2 \pm 3.1$ & $12.7 \pm 7.7$ \\
\hline Cell Saver Returned (mL) & $74.6 \pm 56.2$ & $96.6 \pm 58.3$ \\
\hline Total Fluids Transfused (mL) & $2114.7 \pm 510.3$ & $2461.0 \pm 693.0$ \\
\hline Operative Time (min) & $197.7 \pm 61.5$ & $265.2 \pm 53.4$ \\
\hline \multicolumn{3}{|l|}{ Postoperative Outcomes } \\
\hline Hemoglobin POD 1 (g/dL) & $11.5 \pm 1.2$ & $10.6 \pm 2.2$ \\
\hline Hemoglobin POD 2 (g/dL) & $10.6 \pm 1.1$ & $9.8 \pm 2.0$ \\
\hline Decrease in Hemoglobin ( $\mathrm{g} / \mathrm{dL})$ & $2.7 \pm 0.9$ & $3.9 \pm 2.9$ \\
\hline Number of Days in ICU & 0 & $1.2 \pm 2.2$ \\
\hline Length of Stay in Hospital (days) & $4.9 \pm 0.6$ & $5.4 \pm 2.1$ \\
\hline In-hospital Complications (n, \%) & 0 & $1(20 \%)$ \\
\hline Late Complications (n, \%) & 0 & $2(40 \%)$ \\
\hline
\end{tabular}

$B M I$ Body mass index, EBL Estimated blood loss, AIS Adolescent idiopathic scoliosis, JIS Juvenile idiopathic scoliosis, \% EBVL Percent estimated blood volume loss, $P O D$ Postoperative day

\section{Discussion}

Blood loss is considered to be a major cause of morbidity in pediatric spinal deformity surgery. However, blood transfusions involve various risks and may be refused due to personal or religious reasons, most notably by the Jehovah's Witnesses. Surgical treatment of these patients presents unique challenges for physicians and medical staff, as they require rigorous preoperative evaluation and the combined use of numerous blood conservation techniques. It is thus important to emphasize that the practicability and efficacy of performing such procedures in those who refuse transfusions depends on having an experienced multidisciplinary team, which typically consists of hematologists, surgeons, anesthesiologists, and other surgical personnel. All of our patients in this series underwent standard preoperative and surgical techniques as described in our methods. Blood conservation techniques used included iron supplementation, hypotensive anesthesia, intraoperative cell salvage, tranexamic acid, electrocautery and bipolar tissue sealants, and ultrasonic bone cutting devices. Average blood loss was $307.9 \mathrm{~mL}$, which is lower than the average blood loss for posterior spinal fusion in pediatric scoliosis patients $(500 \mathrm{~mL}-1000 \mathrm{~mL})$ [1]. The average postoperative hemoglobin was $10.5 \mathrm{~g} / \mathrm{dL}$, with the lowest being $7.3 \mathrm{~g} /$ $\mathrm{dL}$, which occurred in a patient with neuromuscular scoliosis who underwent fusion from T2 to the pelvis. The patients in our series had an average improvement in their major coronal Cobb angle from $55.4^{\circ}$ to $11.1^{\circ}$ (correction of $80 \%, p<0.001$ ), with minimal complications. Specifically, average improvement in the major coronal Cobb angle was $49.6 \pm 6.4^{\circ}$ to $7.8 \pm 3.1^{\circ}$ (correction of $84 \%, p<0.001)$ in the idiopathic group and $72.8 \pm 29.4^{\circ}$ to $21.0 \pm 11.8^{\circ}$ (correction of $71 \%, p=0.005$ ) in the non-idiopathic group (Table 2).

Hypotensive anesthesia (HA) is a well-documented method for reducing blood loss [22-24]. A notable 1992 study by Brodsky et al. showed that HA reduced blood loss in JW patients undergoing scoliosis surgery compared to case-matched controls who received normotensive anesthesia [22]. However, the JW patients who received $\mathrm{HA}$ also had shorter operative times, and this study determined that the most important determinant of blood loss is operative technique. Furthermore, Sum et al. demonstrated that using HA in scoliosis surgery decreased average blood loss by $55 \%$, reduced the need for transfusion by $53 \%$, and shortened average operative time by $81 \mathrm{~min}$ [40]. Although one concern regarding HA in spine surgery is the risk of spinal cord ischemia, especially when combined with $\mathrm{ANH}$, current literature supports its use [41, 42].

Intraoperative cell salvage (ICS) or cell saver is the process of collecting blood lost during surgery for the purpose of filtering red blood cells for reinfusion. ICS was employed for all of our patients (average reinfusion of $80 \mathrm{~mL}$ ) since majority of JW patients accept this blood conservation method as long as its equipment remains continuous with their circulation [9]. Several studies have shown ICS reduces the need for transfusion in scoliosis patients undergoing posterior spinal fusion [26-28]. In addition, a 2017 systematic review by Stone et al. claimed that ICS may be cost effective when considering the total costs involved with allogeneic blood transfusions [27]. Cost comparison of ICS and blood 


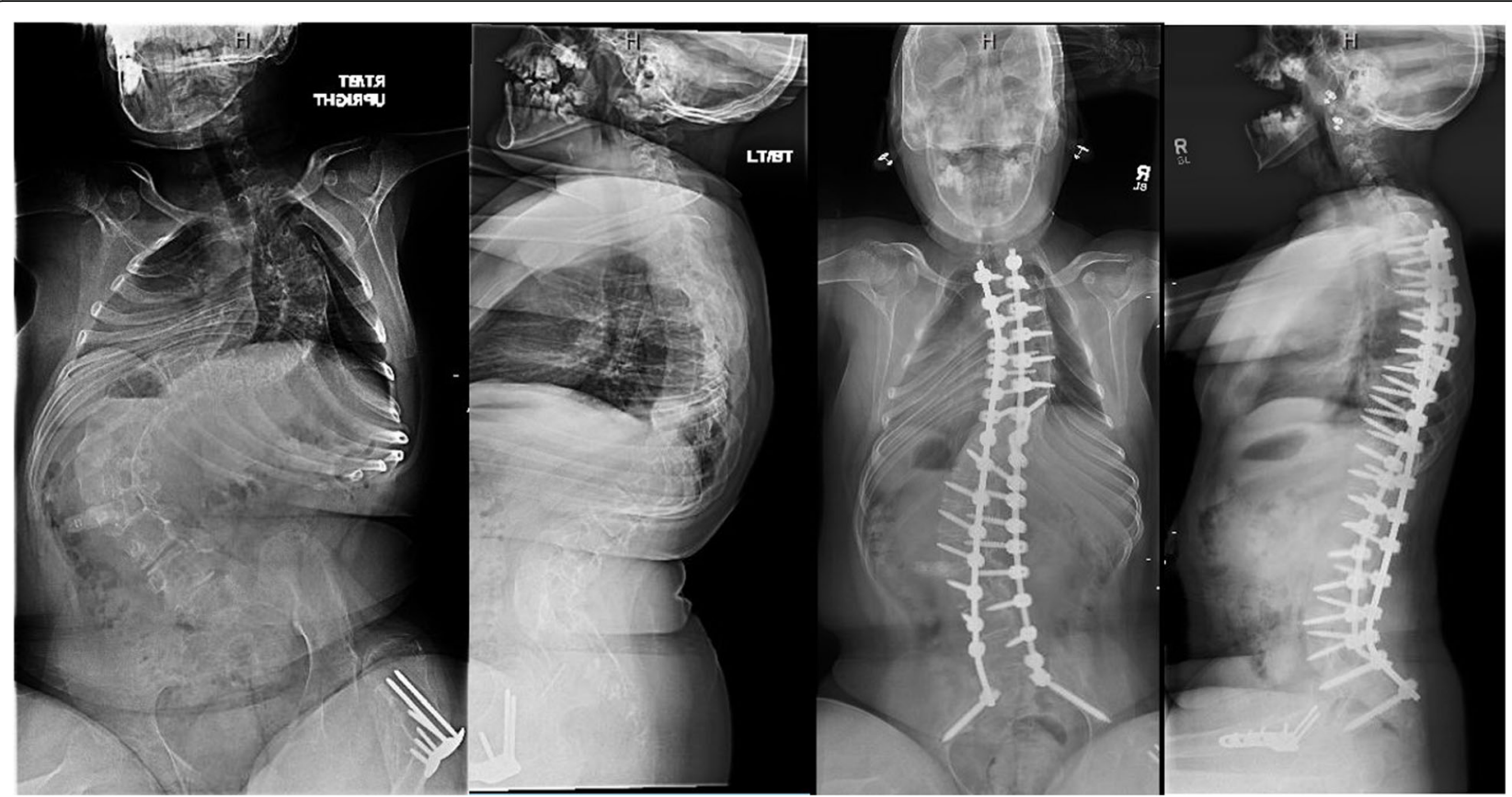

Fig. 1 Pre- and 1-year postoperative anteroposterior and lateral radiographs of a 13-year-old female with spastic quadriplegic cerebral palsy treated by posterior spinal fusion from T2 to pelvis showing satisfactory correction. Intraoperative blood loss was $400 \mathrm{~mL}$ and perioperative decrease in $\mathrm{Hb}$ was $2.3 \mathrm{mg} / \mathrm{dL}$

transfusions is clearly not a factor in patients who refuse transfusions.

Numerous studies have demonstrated that antifibrinolytics reduce perioperative blood loss and transfusion rates in pediatric patients undergoing scoliosis surgery [30-35]. In a study by Grant et al. on the comparative efficacy of high-dose TXA $(20 \mathrm{mg} / \mathrm{kg}$ loading, $10 \mathrm{mg} / \mathrm{kg} /$ hr. maintenance) vs. low-dose TXA $(10 \mathrm{mg} / \mathrm{kg}$ loading, $1 \mathrm{mg} / \mathrm{kg} / \mathrm{hr}$. maintenance), the authors reported that high-dose TXA showed a trend toward a reduction in transfusion requirements compared to low-dose TXA [43]. Based on the above data, literature from adult

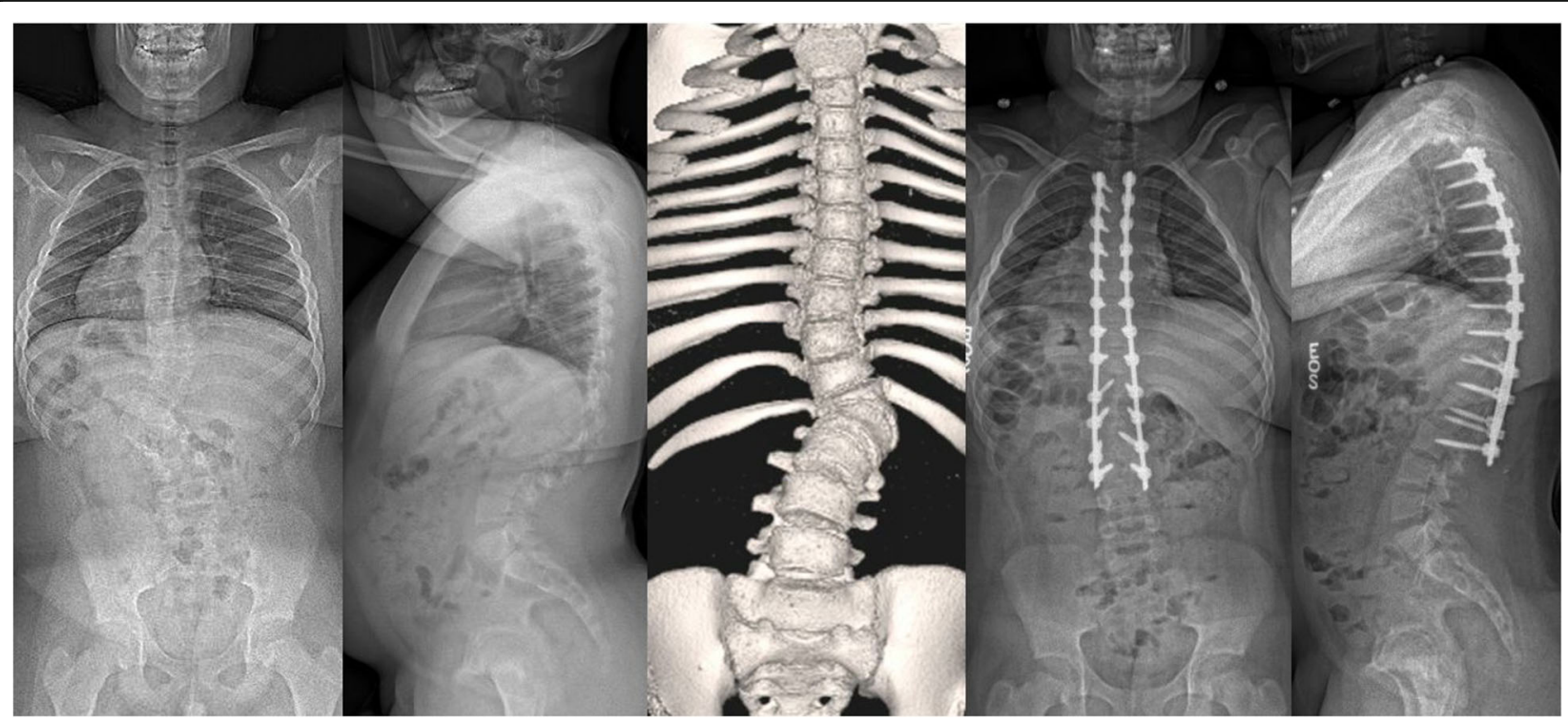

Fig. 2 Pre- and 2-year postoperative anteroposterior and lateral radiographs and 3D CT of a 13-year-old male with congenital scoliosis treated by posterior spinal fusion with L1-hemivertebra resection. Intraoperative blood loss was $100 \mathrm{~mL}$. The 2-year postoperative radiographs show presence of radiographic distal junctional kyphosis which remains asymptomatic 
Table 2 Comparison of preoperative to postoperative radiographic and clinical variables in adolescent patients with spinal deformity correction who refused blood transfusion

\begin{tabular}{|c|c|c|c|}
\hline & Preoperative & Postoperative & $P$ value \\
\hline \multicolumn{4}{|c|}{ Coronal major Cobb angle } \\
\hline Idiopathic & $49.6 \pm 6.4^{\circ}$ & $7.8 \pm 3.1^{\circ}$ & $<0.001$ \\
\hline Non-Idiopathic & $72.8 \pm 29.4^{\circ}$ & $21.0 \pm 11.8^{\circ}$ & 0.005 \\
\hline \multicolumn{4}{|l|}{ Thoracic kyphosis } \\
\hline Idiopathic & $27.8 \pm 11.1^{\circ}$ & $33.6 \pm 8.4^{\circ}$ & 0.005 \\
\hline Non-Idiopathic & $49.8 \pm 18.2^{\circ}$ & $40.4 \pm 7.1^{\circ}$ & 0.237 \\
\hline \multicolumn{4}{|l|}{ Lumbar lordosis } \\
\hline Idiopathic & $49.9 \pm 10.5^{\circ}$ & $52.5 \pm 8.3^{\circ}$ & 0.184 \\
\hline Non-Idiopathic & $51.2 \pm 14.0^{\circ}$ & $49.2 \pm 9.4^{\circ}$ & 0.733 \\
\hline \multicolumn{4}{|c|}{ Hemoglobin $^{a}(g / d L)$} \\
\hline Idiopathic & $13.3 \pm 0.9$ & $10.6 \pm 1.1$ & $<0.001$ \\
\hline Non-Idiopathic & $13.8 \pm 1.5$ & $9.8 \pm 2.0$ & 0.169 \\
\hline
\end{tabular}

$P$ values in bold represent significance.

${ }^{a}$ Comparison made between preoperative and postoperative day 2 values

populations, and our own clinical experience, we use a loading dose of $50 \mathrm{mg} / \mathrm{kg}$ and a maintenance dose of 5 $\mathrm{mg} / \mathrm{kg} / \mathrm{hr}$. [44]. Analogous to systemic TXA, topical TXA has been used in various surgical specialties to decrease perioperative blood loss. Although current evidence is limited in the spine literature $[45,46]$, topical TXA used in total joint arthroplasty procedures has shown significant promising results [47, 48]. In a placebo-controlled study, Krohn et al. investigated the impact of topical TXA on postoperative blood loss in patients undergoing elective lumbar spine fusions and found that $2-5 \mathrm{~min}$ of locally applied TXA solution before wound closure reduced the postoperative drain output by $50 \%$ [49]. At our institute, we use topical TXA in the form of sponges soaked in $1 \mathrm{~g}$ TXA in $100 \mathrm{ml}$ of normal saline to be used to pack the wound during different stages of the procedure including the end of exposure, thoracoplasty, and during instrumentation.

The use of ultrasonic bone cutting tools in pediatric spinal deformity surgery is relatively recent, particularly for osteotomies and facetectomies, owing to their tissue selectivity and ability to reduce blood loss [37, 38]. The blades of these tools operate via short excursions at frequencies of over 22,500 oscillations per second. On contact, these repetitive impacts sever rigid structures while soft tissues are much less affected due to their elasticity. Furthermore, these tools reduce bleeding from bone decortication by cauterizing cancellous bone, which is responsible for most of the blood loss in posterior spinal fusion [22]. A study by Bartley et al. was the first to investigate the effects of ultrasonic bone scalpels (UBS) on reducing blood loss in AIS patients undergoing posterior spinal fusion [37]. In the UBS group, UBS was used for facetectomies and apical Ponte-type posterior releases, while standard osteotomes and rongeurs were used in the control groups. The UBS group had 30 to $40 \%$ less blood loss, as well as less cell saver transfused and blood loss per level fused, compared to controls. Operative times were identical among all groups. A 2019 study by Wahlquist et al. corroborated these results, including in patients with neuromuscular scoliosis [38].

Our study has several limitations. First, we have a small sample size. Although the relative size of our target population makes it difficult to gather a larger sample size, it is from a single center, which further makes our results less generalizable. Second, we cannot make confident conclusions regarding the ideal blood conservation protocol for this patient population as we lack a control group. Third, multiple blood conservation techniques were used in each patient, so we are unable determine which specific methods are the most efficacious. Lastly, our study was a retrospective review.

\section{Conclusions}

In summary, through the use of iron supplementation, hypotensive anesthesia, intraoperative cell salvage, tranexamic acid, and ultrasonic bone cutting tools, surgical correction of spinal deformities can be safely performed in adolescent patients refusing blood transfusion with excellent deformity correction and minimal complications, by an experienced multidisciplinary team. Our study adds to the scarce body of literature on the use of blood conservation protocols in this patient population, who present ethical, clinical, and medicolegal challenges for healthcare providers. Importantly, such protocols are not only applicable to those who refuse transfusions, but also all patients as their use can minimize blood loss and the need for blood transfusions, which are limited and expensive resources that are associated with various known risks.

\section{Abbreviations \\ BMI: Body mass index; EBL: Estimated blood loss; \% EBVL: Percent estimated blood volume loss; EBV: Estimated blood volume; AIS: Adolescent idiopathic scoliosis; JIS: Juvenile idiopathic scoliosis; UBS: Ultrasonic bone scalpel; JW: Jehovah's Witness; HA: Hypotensive anesthesia; ANH: Normovolemic hemodilution; ICS: Intraoperative cell salvage; TXA: Tranexamic acid; POD: Postoperative day}

\section{Acknowledgements}

Not applicable.

\section{Authors' contributions}

AM: Conception and design, data acquisition, analysis, interpretation, drafting, critical revision, and final approval. SuR: Conception and design, data acquisition, oversight, analysis, drafting, critical revision, and final approval. SeR: Conception and design, drafting, critical revision, and final approval. AMansour: Conception and design, drafting, critical revision, and final approval. JA: Data acquisition, interpretation, critical revision, and final approval. HS: Data acquisition, interpretation, critical revision, and final approval. SG: Data acquisition, interpretation, critical revision, and final approval. 


\section{Funding}

No funding source was provided for this study.

\section{Availability of data and materials}

The datasets used and/or analyzed during the current study are available from the corresponding author on reasonable request.

\section{Ethics approval and consent to participate}

IRB approval was obtained before the initiation of the study. Western Institutional Review Boards number- 2019064RI.

\section{Consent for publication}

Not applicable.

\section{Competing interests}

AM (none), SR (none), SR (none), AM (none), JA (none), HS (Depuy Synthes \& Stryker K2M; consultant, speaker's bureau, and royalties), SG (Globus Medical: consultant).

\section{Author details}

${ }^{1}$ Florida International University Herbert Wertheim College of Medicine, 11200 SW 8th Street, Miami, FL 33199, USA. ²Department of Orthopedic Surgery, Nicklaus Children's Hospital, 3100 SW 62nd Avenue, Miami, FL 33155, USA. ${ }^{3}$ Department of Orthopedic Surgery, Jackson Memorial Hospital, University of Miami, 1611 NW 12th Avenue, Miami, FL 33136, USA. ${ }^{4}$ Cantor Spine Institute, 3000 Bayview Drive Suite 200, Fort Lauderdale, FL 33306, USA. ${ }^{5}$ Paley Orthopedic and Spine Institute at St. Mary's Medical Center, 901 45th Street, West Palm Beach, FL 33407, USA.

\section{Received: 24 September 2020 Accepted: 11 February 2021}

\section{Published online: 19 February 2021}

\section{References}

1. Shapiro F, Sethna N. Blood loss in pediatric spine surgery. Eur Spine J. 2004; 13(Suppl 1):S6-17. https://doi.org/10.1007/s00586-004-0760-y.

2. Jain A, Sponseller PD, Newton PO, Shah SA, Cahill PJ, Njoku DB, Betz RR, Samdani AF, Bastrom TP, Marks MC, Harms Study G. Smaller body size increases the percentage of blood volume lost during posterior spinal arthrodesis. J Bone Joint Surg Am. 2015;97(6):507-11. https://doi.org/10.21 06/JBJS.N.01104

3. Vigneswaran HT, Grabel ZJ, Eberson CP, Palumbo MA, Daniels AH. Surgical treatment of adolescent idiopathic scoliosis in the United States from 1997 to 2012: an analysis of 20,346 patients. J Neurosurg Pediatr. 2015;16(3):3228. https://doi.org/10.3171/2015.3.PEDS14649.

4. Mange TR, Sucato DJ, Poppino KF, Jo CH, Ramo BR. The incidence and risk factors for perioperative allogeneic blood transfusion in primary idiopathic scoliosis surgery. Spine Deform. 2020. https://doi.org/10.1007/s43390-02000093-6.

5. Ohrt-Nissen S, Bukhari N, Dragsted C, Gehrchen M, Johansson Pl, Dirks J, Stensballe J, Dahl B. Blood transfusion in the surgical treatment of adolescent idiopathic scoliosis-a single-center experience of patient blood management in 210 cases. Transfusion. 2017;57(7):1808-17. https://doi.org/1 $0.1111 /$ trf.14137

6. Lavoie J. Blood transfusion risks and alternative strategies in pediatric patients. Paediatr Anaesth. 2011;21(1):14-24. https://doi.org/10.1111/j.14609592.2010.03470x

7. Ponnusamy KE, Kim TJ, Khanuja HS. Perioperative blood transfusions in orthopaedic surgery. J Bone Joint Surg Am. 2014;96(21):1836-44. https://doi. org/10.2106/JBJS.N.00128.

8. Seicean A, Alan N, Seicean S, Neuhauser D, Weil RJ. The effect of blood transfusion on short-term, perioperative outcomes in elective spine surgery. J Clin Neurosci. 2014;21(9):1579-85. https://doi.org/10.1016/j.jocn.2014.03. 003.

9. Bodnaruk ZM, Wong CJ, Thomas MJ. Meeting the clinical challenge of care for Jehovah's witnesses. Transfus Med Rev. 2004;18(2):105-16.

10. Watch Tower Bible and Tract Society (2000). Questions from readers. The Watchtower; 2000. p. 29-31.

11. Jones JW, McCullough LB, Richman BW. Painted into a corner: unexpected complications in treating a Jehovah's witness. J Vasc Surg. 2006:44(2):425-8. https://doi.org/10.1016/j.jvs.2006.05.001.
12. Lin ES, Kaye AD, Baluch AR. Preanesthetic assessment of the Jehovah's witness patient. Ochsner J. 2012;12(1):61-9.

13. Scharman CD, Burger D, Shatzel JJ, Kim E, DeLoughery TG. Treatment of individuals who cannot receive blood products for religious or other reasons. Am J Hematol. 2017;92(12):1370-81. https://doi.org/10.1002/ajh.24 889.

14. Bamberger DH. Mercy Hospital, Inc v Jackson: a recurring dilemma for health care providers in the treatment of Jehovah's Witnesses. MD Law Rev. 1987;46(3):514-32

15. Woolley S. Children of Jehovah's witnesses and adolescent Jehovah's witnesses: what are their rights? Arch Dis Child. 2005;90(7):715-9. https:// doi.org/10.1136/adc.2004.067843.

16. Joseph SA Jr, Berekashvili K, Mariller MM, Rivlin M, Sharma K, Casden A, Bitan F, Kuflik P, Neuwirth M. Blood conservation techniques in spinal deformity surgery: a retrospective review of patients refusing blood transfusion. Spine (Phila Pa 1976). 2008;33(21):2310-5. https://doi.org/10.1 097/BRS.0b013e31818047f2.

17. Koerner JD, Patel A, Zhao C, Schoenberg C, Mishra A, Vives MJ, Sabharwal S Blood loss during posterior spinal fusion for adolescent idiopathic scoliosis. Spine (Phila Pa 1976). 2014;39(18):1479-87. https://doi.org/10.1097/BRS. 0000000000000439

18. Resar LM, Frank SM. Bloodless medicine: what to do when you can't transfuse. Hematology Am Soc Hematol Educ Program. 2014;2014(1):553-8. https://doi.org/10.1182/asheducation-2014.1.553.

19. Colomina MJ, Bago J, Pellise F, Godet C, Villanueva C. Preoperative erythropoietin in spine surgery. Eur Spine J. 2004;13(Suppl 1):S40-9. https:// doi.org/10.1007/s00586-004-0754-9.

20. Vitale MG, Levy DE, Park MC, Choi H, Choe JC, Roye DP Jr. Quantifying risk of transfusion in children undergoing spine surgery. Spine J. 2002;2(3):166-72.

21. Bible JE, Mirza M, Knaub MA. Blood-loss Management in Spine Surgery. J Am Acad Orthop Surg. 2018;26(2):35-44. https://doi.org/10.5435/JAAOS-D-1 6-00184.

22. Brodsky JW, Dickson JH, Erwin WD, Rossi CD. Hypotensive anesthesia for scoliosis surgery in Jehovah's witnesses. Spine (Phila Pa 1976). 1991;16(3): 304-6.

23. Malcolm-Smith NA, McMaster MJ. The use of induced hypotension to control bleeding during posterior fusion for scoliosis. J Bone Joint Surg Br. 1983;65(3):255-8.

24. Kawano H, Manabe S, Matsumoto T, Hamaguchi E, Kinoshita M, Tada F, Oshita S. Comparison of intraoperative blood loss during spinal surgery using either remifentanil or fentanyl as an adjuvant to general anesthesia. BMC Anesthesiol. 2013;13(1):46. https://doi.org/10.1186/1471-2253-13-46.

25. Copley LA, Richards BS, Safavi FZ, Newton PO. Hemodilution as a method to reduce transfusion requirements in adolescent spine fusion surgery. Spine (Phila Pa 1976). 1999;24(3):219-22 discussion 223-214.

26. Liang J, Shen J, Chua S, Fan Y, Zhai J, Feng B, Cai S, Li Z, Xue X. Does intraoperative cell salvage system effectively decrease the need for allogeneic transfusions in scoliotic patients undergoing posterior spinal fusion? A prospective randomized study. Eur Spine J. 2015:24(2):270-5. https://doi.org/10.1007/s00586-014-3282-2.

27. Stone N, Sardana V, Missiuna P. Indications and outcomes of cell saver in adolescent scoliosis correction surgery: a systematic review. Spine (Phila Pa 1976). 2017:42(6):E363-70. https://doi.org/10.1097/BRS.0000000000001780.

28. Bowen RE, Gardner S, Scaduto AA, Eagan M, Beckstead J. Efficacy of intraoperative cell salvage systems in pediatric idiopathic scoliosis patients undergoing posterior spinal fusion with segmental spinal instrumentation. Spine (Phila Pa 1976). 2010;35(2):246-51. https://doi.org/10.1097/BRS.0b013 e3181bdf22a.

29. Abbott EM, Nandyala SV, Schwend RM. Does a kaolin-impregnated hemostatic dressing reduce intraoperative blood loss and blood transfusions in pediatric spinal deformity surgery? Spine (Phila Pa 1976). 2014:39(19):E1174-80. https://doi.org/10.1097/BRS.0000000000000466.

30. Verma K, Errico T, Diefenbach C, Hoelscher C, Peters A, Dryer J, Huncke T, Boenigk K, Lonner BS. The relative efficacy of antifibrinolytics in adolescent idiopathic scoliosis: a prospective randomized trial. J Bone Joint Surg Am. 2014;96(10):e80. https://doi.org/10.2106/JBJS.L.00008.

31. Yagi M, Hasegawa J, Nagoshi N, lizuka S, Kaneko S, Fukuda K, Takemitsu M, Shioda M, Machida M. Does the intraoperative tranexamic acid decrease operative blood loss during posterior spinal fusion for treatment of adolescent idiopathic scoliosis? Spine (Phila Pa 1976). 2012:37(21):E1336-42. https://doi.org/10.1097/BRS.0b013e318266b6e5. 
32. Thompson GH, Florentino-Pineda I, Poe-Kochert C. The role of amicar in decreasing perioperative blood loss in idiopathic scoliosis. Spine (Phila Pa 1976). 2005;30(17 Suppl):S94-9.

33. Shapiro F, Zurakowski D, Sethna NF. Tranexamic acid diminishes intraoperative blood loss and transfusion in spinal fusions for duchenne muscular dystrophy scoliosis. Spine (Phila Pa 1976). 2007;32(20):2278-83. https://doi.org/10.1097/BRS.0b013e31814cf139.

34. Sethna NF, Zurakowski D, Brustowicz RM, Bacsik J, Sullivan LJ, Shapiro F. Tranexamic acid reduces intraoperative blood loss in pediatric patients undergoing scoliosis surgery. Anesthesiology. 2005;102(4):727-32.

35. Elwatidy S, Jamjoom Z, Elgamal E, Zakaria A, Turkistani A, El-Dawlatly A. Efficacy and safety of prophylactic large dose of tranexamic acid in spine surgery: a prospective, randomized, double-blind, placebo-controlled study. Spine (Phila Pa 1976). 2008;33(24):2577-80. https://doi.org/10.1097/BRS. Ob013e318188b9c5.

36. Hill SE, Broomer B, Stover J, White W, Richardson W. Bipolar tissue sealant device decreases hemoglobin loss in multilevel spine surgery. Transfusion. 2012;52(12):2594-9. https://doi.org/10.1111/j.1537-2995.2012.03649.x.

37. Bartley CE, Bastrom TP, Newton PO. Blood loss reduction during surgical correction of adolescent idiopathic scoliosis utilizing an ultrasonic bone scalpel. Spine Deform. 2014;2(4):285-90. https://doi.org/10.1016/j.jppd.2014. 03.008 .

38. Wahlquist $\mathrm{S}$, Nelson S, Glivar P. Effect of the ultrasonic bone scalpel on blood loss during pediatric spinal deformity correction surgery. Spine Deform. 2019;7(4):582-7. https://doi.org/10.1016/j.jspd.2018.10.002.

39. Hoashi J, Brimmo O, Kolmodin J, Gurd D, Kuivila T. Surgical Management of Scoliosis in Jehovah's witness patients: one Institution's experience. J Spine. 2015;4(223):2.

40. Sum DC, Chung PC, Chen WC. Deliberate hypotensive anesthesia with labetalol in reconstructive surgery for scoliosis. Acta Anaesthesiol Sin. 1996; 34(4):203-7.

41. Oetgen ME, Litrenta J. Perioperative blood Management in Pediatric Spine Surgery. J Am Acad Orthop Surg. 2017;25(7):480-8. https://doi.org/10.5435/ JAAOS-D-16-00035.

42. Lim YJ, Kim CS, Bahk JH, Ham BM, Do SH. Clinical trial of esmolol-induced controlled hypotension with or without acute normovolemic hemodilution in spinal surgery. Acta Anaesthesiol Scand. 2003;47(1):74-8. https://doi.org/1 0.1034/j.1399-6576.2003.470113.x

43. Grant JA, Howard J, Luntley J, Harder J, Aleissa S, Parsons D. Perioperative blood transfusion requirements in pediatric scoliosis surgery: the efficacy of tranexamic acid. J Pediatr Orthop. 2009;29(3):300-4. https://doi.org/10.1097/ BPO.0b013e31819a85de.

44. Goobie SM, Zurakowski D, Glotzbecker MP, McCann ME, Hedequist D, Brustowicz RM, Sethna NF, Karlin LI, Emans JB, Hresko MT. Tranexamic acid is efficacious at decreasing the rate of blood loss in adolescent scoliosis surgery: a randomized placebo-controlled trial. J Bone Joint Surg Am. 2018; 100(23):2024-32. https://doi.org/10.2106/JBJS.18.00314.

45. Yerneni K, Burke JF, Tuchman A, Li XJ, Metz LN, Lehman RA Jr, Lenke LG, Tan LA. Topical tranexamic acid in spinal surgery: a systematic review and meta-analysis. J Clin Neurosci. 2019;61:114-9. https://doi.org/10.1016/.jocn.2 018.10.121.

46. Fatima N, Barra ME, Roberts RJ, Massaad E, Hadzipasic M, Shankar GM, Shin $\mathrm{JH}$. Advances in surgical hemostasis: a comprehensive review and metaanalysis on topical tranexamic acid in spinal deformity surgery. Neurosurg Rev. 2020. https://doi.org/10.1007/s10143-020-01236-z.

47. Georgiadis AG, Muh SJ, Silverton CD, Weir RM, Laker MW. A prospective double-blind placebo controlled trial of topical tranexamic acid in total knee arthroplasty. J Arthroplast. 2013;28(8 Suppl):78-82. https://doi.org/10.1 016/j.arth.2013.03.038.

48. Patel JN, Spanyer JM, Smith LS, Huang J, Yakkanti MR, Malkani AL. Comparison of intravenous versus topical tranexamic acid in total knee arthroplasty: a prospective randomized study. J Arthroplast. 2014;29(8):152831. https://doi.org/10.1016/j.arth.2014.03.011

49. Krohn CD, Sorensen R, Lange JE, Riise R, Bjornsen S, Brosstad F. Tranexamic acid given into the wound reduces postoperative blood loss by half in major orthopaedic surgery. Eur J Surg Suppl. 2003;588:57-61.

\section{Publisher's Note}

Springer Nature remains neutral with regard to jurisdictional claims in published maps and institutional affiliations.

\section{Ready to submit your research? Choose BMC and benefit from}

- fast, convenient online submission

- thorough peer review by experienced researchers in your field

- rapid publication on acceptance

- support for research data, including large and complex data types

- gold Open Access which fosters wider collaboration and increased citations

- maximum visibility for your research: over $100 \mathrm{M}$ website views per year

At $\mathrm{BMC}$, research is always in progress.

Learn more biomedcentral.com/submissions 